\title{
EFFICIENT RECONSTRUCTION OF ENGINEERING BUILDINGS IN CONDITIONS OF ORGANIZATIONAL CONSTRAINTS
}

\author{
A. L. Nikiforov ${ }^{1}$, i. A. Menejljuk ${ }^{1}$, m. N. Ershov $^{2}$ \\ ${ }^{1}$ Odessa State Academy of Civil Engineering and Architecture \\ ${ }^{2}$ Moskow State Building University
}

Copyright (C) 2014 by author and the journal “Automation technological and business - processes". This work is licensed under the Creative Commons Attribution International License (CC BY). http://creativecommons.org/licenses/by/4.0/

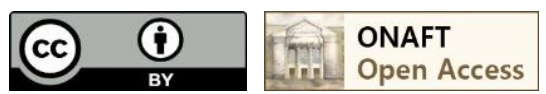

\begin{abstract}
Annotation
The article presents the results of experimental and statistical modeling and the search for effective organizational solutions for reconstruction of high-rise engineering structures by the example of the Ostankino television tower. The dependences of the factors having the greatest impact on the studied parameters are found. Restrictions on possible organizational solutions, on effectiveness indicators are imposed. According to the analysis of diagrams containing restrictions the most efficient organizational options for reconstruction are recommended.
\end{abstract}

Ключовые слова

Experimental statistical modeling, reconstruction, high-rise engineering structures, numerical methods of optimization.

Introduction

In Ukraine and abroad a large number of high-rise engineering structures is placed. Most of them are operated for ten years or more. Many high-rise engineering facilities require repair work, and some - emergency repair. Such projects require a significant investment. As a rule, there are many options for the upgrade. They may have different costs, deadlines. The uniqueness of some objects requires a specific work schedule (only on the night shift, the use of a limited number of people or calendar time). The regulations and studied information sources have no guidelines for the selection of effective organizational and technological solutions in the reconstruction of such facilities. Therefore, such work requires modeling and subsequent optimization on the most important criteria.

Using traditional building process modeling methods makes it impossible to assess the effectiveness of variants of organizational and technological solutions. Modeling and analysis of such options by experimental statistical methods will determine the best solution for the selected performance criteria.

The purpose and objectives of the study

The aim of this study is to search for effective organizational solutions for reconstruction of high-rise engineering structures in the conditions of the limitations specified by experimental and statistical modeling on the example of the Ostankino television tower. To achieve this goal it is necessary to solve the following tasks:

1. Development of numerical optimization algorithm of organizational solutions, using experimental statistical modeling of the reconstruction project.

2. Carrying out a numerical experiment and build analytical and graphical dependences of the studied parameters of organizational factors.

3. Recommendation of the best options for the production of works on reconstruction at the given organizational constraints. 
To solve the optimization problem of the reconstruction project Ostankino television tower the numerical experiment on modeling options of organizational solutions to these works was carried out. When carrying out a numerical study the theory of optimal experimental design, experimental statistical modeling, advanced software for the construction of the calendar-network models construction industry was used $[1,2,3]$.

The numerical study on the developed algorithm can reasonably choose the optimal organizational solutions for the complex restoration work in difficult conditions, with limited institutional financing [4]. The study estimates was used to reflect the actual costs of construction and installation works. Building construction schedules allowed displaying the sequence correctly and technological solutions adopted during the high-altitude installations. Thus, the present study provides a quantitative assessment of alternatives to the project with varying versions of the complex organization of restoration work, financing and conditions of existing restrictions.

Problem solving optimization consists of the steps shown in Fig. 1.

The analysis of information available on the project of reconstruction.

\section{ए}

Selection of the most important indicators and factors influencing them. The design of the experiment plan.

Modeling reconstruction process in accordance with the experiment plan.

\section{r}

Building of experimental statistical models, reflecting the dependence of the factors on performance.

Graphic processing of the results of the numerical experiment.

\section{Xz}

Analysis of the results of the numerical experiment.

Fig. 1 - Flowchart of the research methods

The object of optimization is the project of reconstruction of the Ostankino television tower, which is located in Moscow. The tower is one of the highest buildings of this type in the world, has a series of non-standard design solutions, as well as the peculiarities of production, which greatly complicates the process of reconstruction. As a result of analysis of the features of the object, we identified the main indicators of the reconstruction project, as well as factors that directly affect these figures.

The following indicators are the most important in our view:

$\mathrm{y}_{1}$ - the duration of construction and installation works;

$\mathrm{y}_{2}-$ the intensity of the financing of the reconstruction project;

$\mathrm{y}_{3}$ - the cost of construction and installation works.

On selected indicators most influenced by the following factors:

$X_{1}$ - the number of shifts per day;

$\mathrm{X}_{2}$ - the number of working days;

$\mathrm{X}_{3}$ - ratio combining work;

$\mathrm{X}_{4}$ - the value of fixed costs.

As a result of the construction of the project of reconstruction models (calendar schedules of production) performance of investment and construction project have been investigated, changing under the influence of organizational factors. The results of the study are shown in Table 1.

The pattern of changes of the indicators in the reconstruction of the Ostankino television tower, depending on the number of shifts per day, days per week, the ratio of combining work and the value of fixed costs are adequately described by mathematical models, shown below:

- the duration of construction and installation works;

$$
\begin{gathered}
\mathrm{Y}_{1}=711-477,7 \mathrm{X}_{1}+328,8 \mathrm{X}_{1}^{2}+136,3 \mathrm{X}_{1} \mathrm{X}_{2}+233 \mathrm{X}_{1} \mathrm{X}_{3} \\
-362,6 \mathrm{X}_{2}+260,3 \mathrm{X}_{2}^{2}+180,9 \mathrm{X}_{2} \mathrm{X}_{3} \\
-590,5 \mathrm{X}_{3}+49,8 \mathrm{X}_{3}^{2} \\
\bullet \quad+37,3 \mathrm{X}_{4}^{2}
\end{gathered}
$$




\section{ТЕХНІЧНІ ЗАСОБИ ТА ТЕХНОЛОГІЇ В СИСТЕМАХ УПРАВЛІННЯ}

- the cost of construction and installation works;

$$
\begin{aligned}
& Y_{2}=22539,41+5906,812 X_{1}-4465,1 X_{1}^{2}+1423,84 X_{1} X_{2}+2334,77 X_{1} X_{3}+73,43 X_{1} X_{4} \\
& +4584,98 \mathrm{X}_{2}-4336,95 \mathrm{X}_{2}^{2} \\
& +8106,2 \mathrm{X}_{3}+4394,15 \mathrm{X}_{3}^{2} \\
& +1859,23 X_{2} X_{3}-73,43 X_{2} X_{4} \\
& +67,43 \mathrm{X}_{4}-232,85 \mathrm{X}_{4}^{2}
\end{aligned}
$$

- the intensity of the financing of the reconstruction project.

$$
\begin{aligned}
& Y_{3}=543451,34-9628,71 X_{1}+1328,02 X_{1}^{2}+395,83 X_{1} X_{2}+2008,34 X_{1} X_{3}-1391,67 X_{1} X_{4} \\
& -4375,93 \mathrm{X}_{2}+186,32 \mathrm{X}_{2}^{2} \\
& -8175,01 \mathrm{X}_{3}-3321,98 \mathrm{X}_{3}^{2} \\
& +5442,22 X_{4}+11469,67 X_{4}^{2}
\end{aligned}
$$

\begin{tabular}{|c|c|c|c|c|c|c|c|c|c|c|c|c|c|c|c|}
\hline № & 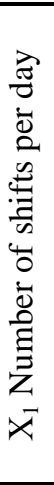 & 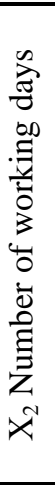 & 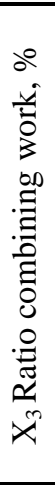 &  &  &  &  & № &  &  & 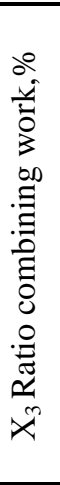 & 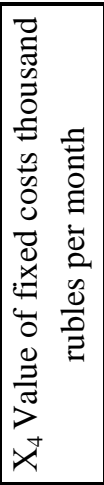 & 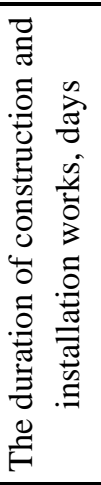 &  & 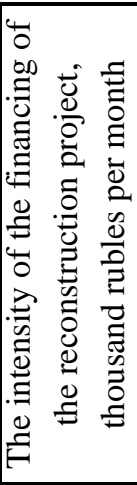 \\
\hline 1 & 2 & 3 & 4 & 5 & 6 & 7 & 8 & 1 & 2 & 3 & 4 & 5 & 6 & 7 & 8 \\
\hline 1 & 3 & 7 & 63 & 700 & 382 & 536955 & 42169 & 13 & 1 & 3 & 63 & 700 & 1282 & 557955 & 13056 \\
\hline 2 & 3 & 7 & 63 & 300 & 382 & 531862 & 41769 & 14 & 1 & 3 & 63 & 300 & 1282 & 540862 & 12656 \\
\hline 3 & 3 & 7 & 0 & 700 & 939 & 549952 & 17570 & 15 & 1 & 3 & 0 & 700 & 3494 & 609568 & 5233 \\
\hline 4 & 3 & 7 & 0 & 300 & 939 & 537432 & 17170 & 16 & 1 & 3 & 0 & 300 & 3494 & 562982 & 4833 \\
\hline 5 & 3 & 3 & 63 & 700 & 638 & 542928 & 25529 & 17 & 3 & 5 & 32 & 500 & 655 & 538958 & 24685 \\
\hline 6 & 3 & 3 & 63 & 300 & 638 & 534422 & 25129 & 18 & 1 & 5 & 32 & 500 & 1414 & 551608 & 11703 \\
\hline 7 & 3 & 3 & 0 & 700 & 1633 & 566145 & 10400 & 19 & 2 & 7 & 32 & 500 & 693 & 539592 & 23358 \\
\hline 8 & 3 & 3 & 0 & 300 & 1633 & 544372 & 10000 & 20 & 2 & 3 & 32 & 500 & 1239 & 548692 & 13285 \\
\hline 9 & 1 & 7 & 63 & 700 & 766 & 545915 & 21380 & 21 & 2 & 5 & 63 & 500 & 409 & 534858 & 39231 \\
\hline 10 & 1 & 7 & 63 & 300 & 766 & 535702 & 20980 & 22 & 2 & 5 & 32 & 700 & 743 & 545378 & 22020 \\
\hline 11 & 1 & 7 & 0 & 700 & 1970 & 574008 & 8741 & 23 & 2 & 5 & 0 & 500 & 1102 & 546408 & 14875 \\
\hline 12 & 1 & 7 & 0 & 300 & 1970 & 547742 & 8341 & 24 & 2 & 5 & 32 & 300 & 743 & 535472 & 21620 \\
\hline & & & & & & & & 25 & 2 & 5 & 32 & 500 & 743 & 540425 & 21820 \\
\hline
\end{tabular}

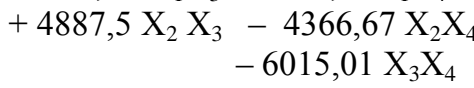

Table 1. Research Results Matrix 
The calculation of the analytical relationships shown above made using program "Compex" developed under the led of Professor V. Voznesensky [5].

Analyzing Fig. 2, we can say that the minimum duration of the construction, which is equal to 790 days, can be obtained at the following values of factors:

- $\quad$ the number of shifts per day $\mathrm{X}_{1}=+0,73$ (22 hours per day);

- the number of working days $\mathrm{X}_{2}=+1$ (7 days a week);

- $\quad$ ratio combining work $\mathrm{X}_{3}=0(32 \%)$;

- the value of fixed costs $\mathrm{X}_{4}=+1$ (700 th. rub per month)

A maximum value of 2314 days, achieved by:

- the number of shifts per day $\mathrm{X}_{1}=-1$ (1 shift a day);

- the number of working days $\mathrm{X}_{2}=-1$ (3 days a week);

- $\quad$ ratio combining work $\mathrm{X}_{3}=0(32 \%)$;

- the value of fixed costs $X_{4}=+1$ (700 th. rub per month)

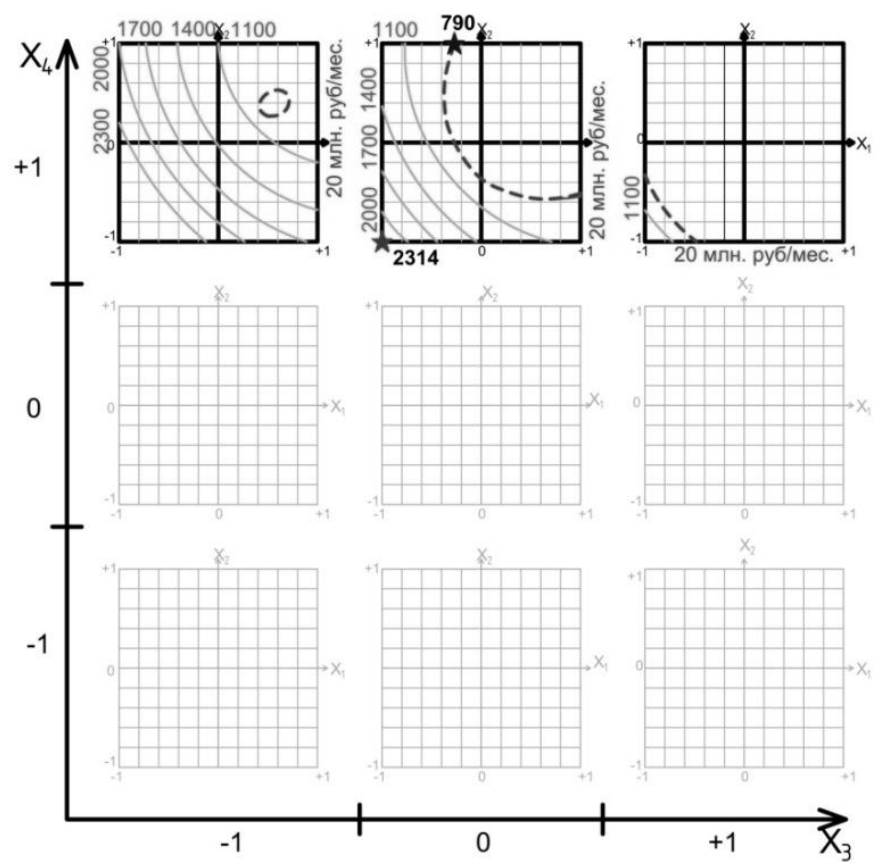

Fig. 2 - Diagram of changing the duration of construction and installation work of the reconstruction with the given constraints ( $\mathrm{y}_{3}=20$ bil. rub. per month., $\mathrm{X}_{4}=700$ th. rub per month.) - dotted line shows the limitation in the intensity of the financing

Restricting leads to the fact that the minimum duration of the reconstruction work is increased by $38.6 \%$ from the specified level in the project documentation of 570 days. At the same time, the maximum value of the studied index decreased by $45.5 \%$ from the extremum obtained as a result of the simulation.

At constant levels of factors X3 and X4 variation of extreme values occurs only by increasing the use of calendar time, ie, to achieve the desired values of the duration of construction and installation work in the reconstruction is necessary to change the values of the factors X1 and X2 (to increase their level for achieving the minimum periods and vice versa, reduce to extend the work performance).

The most rational solution would be to enclose the value of the test indicator to its minimum value specified in the project documentation (570 days). In this case, the minimum value is reached at 790 days by X1 $=0.73$ (22 hours), X2 = 1 ( 7 days a week), X3 = $0(32 \%), \mathrm{X} 4=1$ (700 thousand. rub. / month.).

Choosing this type of restriction is based on the fact that such a situation may arise in case of work in times of financial crisis, when there is no way to preserve the value of the intensity of the financing of the reconstruction project on the initially 


\section{ТЕХНІЧНІ ЗАСОБИ ТА ТЕХНОЛОГІЇ В СИСТЕМАХ УПРАВЛІННЯ}

planned level, and it is necessary to increase the duration of the renovation work to prevent an increase in the total cost of construction and installation work.

An analysis of Fig. 3 shows that the minimum rate of funding of the reconstruction project, which is equal to 11767 thousand rubles per month, can be reached at the following values of the factors:

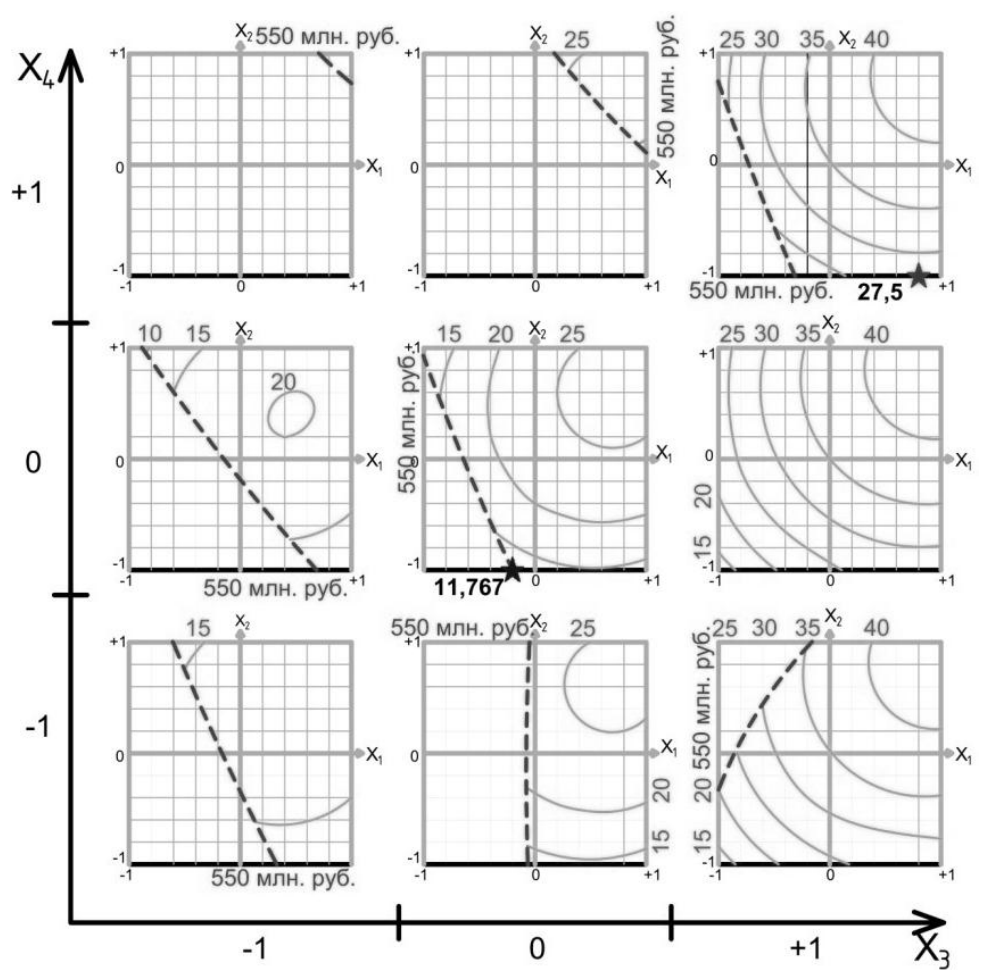

Fig. 3 - Diagram of changing of the intensity of the financing of the reconstruction project $\left(\mathrm{Y}_{2}=550\right.$ bil. rubles, $\mathrm{X}_{2}=3$ days) - dotted line shows the limitation of the cost of construction and installation works

- $\quad$ the number of shifts per day $\mathrm{X}_{1}=+0,8$ (23 hours a day);

- $\quad$ the number of working days $\mathrm{X}_{2}=-1$ (3 days a week);

- $\quad$ ratio combining work $\mathrm{X}_{3}=0(32 \%)$;

- the value of fixed costs $X_{4}=0$ (500 th. rub per month) The maximum value of 27,500 rubles per month is achieved by:

- $\quad$ the number of shifts per day $X_{1}=-0,2$ (16 hours a day);

- the number of working days $\mathrm{X}_{2}=-1$ (3 days a week);

- $\quad$ ratio combining work $\mathrm{X}_{3}=0(32 \%)$;

- the value of fixed costs $\mathrm{X}_{4}=0$ (500 th. rub per month)

As a result of restrictions there was an increase of minimum intensity of financing of the reconstruction project in 1,5 times, and the maximum value of the index has decreased by $54 \%$ compared to the extreme values obtained as a result of the simulation.

This indicator is strongly correlated to the duration and cost of construction and installation works. In this regard, the extreme values of the changes affect all the factors originally given. The analysis of the graphs can be concluded that the most advantageous in all parameters is to carry out the work using works combined ratio of $32 \%$, so to decrease the value of the test indicator need to seek it to the value $X_{3}=0(32 \%)$. If the value $X_{3}=1(63 \%)$ and $X_{3}=-1(0 \%)$ value of the funding intensity tends to a maximum. 
The rational solution would result in the decreasing of the project funding intensity index to a minimum, while the value of construction and installation work cost index should be within the tolerance range. The value of the intensity of financing to 11767 thousand rub. per month is possible to achieve with the values of the factors $X_{1}=0.8(23$ hours $), X_{2}=-1(3$ days a week), $X_{3}=0(32 \%), X_{4}=0$ (500 th. rub. per month).

\section{Conclusions}

1. By limiting the funding intensity (up to $20 \mathrm{mln}$. rubles per month) and the level of fixed costs (not less than 700 th. rubles per month) the minimum duration of the reconstruction, which is equal to 790 days, can be achieved when working 7 days a week in two shifts of 11 hours a day and the reconciliation of work, equal to $32 \%$.

2. By limiting the value of (550 bil. rubles) and the number of working days per week (no more than 3 ), the minimum intensity of the financing of the reconstruction project, which is equal to 11767 th. rubles per month, can be reached at 3 working days per week, 2 shifts of 11.5 hours a day, combining work $32 \%$, the value of fixed costs of 500 th. rubles per month.

\section{References}

[1] Voznesenskij V.A. Statisticheskie metody planirovanija jeksperimenta v tehniko-jekonomicheskih issledovanijah. Moskow.: Finansy i statistika, 1981. Print.;

[2] Adler Ju.P., E.V. Markova and Ju.V. Granovskij. Planirovanie jeksperimenta pri poiske optimal'nyh uslovij. Moskow. Nauka. 1971. Print.;

[3] Nalimov V.V. Teorija jeksperimenta. Moskow. Nauka, 1971. Print.;

[4] Krakovskij G.I. and G.F.Filaretov. Planirovanie jeksperimentov. Minsk: BTU, 1982. Print.;

[5] Voznesenskij V.A., T.V. Ljashenko and B.L. Ogarkov. Chislennye metody reshenija stroitel'no-tehnologicheskih zadach na JeVM. Kiev. :Vishha shkola, 1989. Print.

\section{ПРОСТОЙ ПИ-ПОДОБНЫЙ РЕГУЛЯТОР С КОНТИНУАЛЬНОЙ ЛОГИКОЙ ДЛЯ НЕСТАЦИОНАРНЫХ ОБЪЕКТОВ}

A simple pi-similar controller with continuous logic for non-stationary objects

Павлов А.И. (Pavlov A.I., PhD in Technical Sciences, Associate Professor)

Одесская национальная академия пищевых технологий, Одесса

Copyright (C) 2014 by author and the journal "Automation technological and business - processes". This work is licensed under the Creative Commons Attribution International License (CC BY). http://creativecommons.org/licenses/by/4.0/

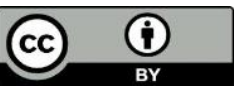

